\title{
Dealing with Linguistic Problems Faced by Master's Students in their Thesis Writing
}

\author{
Adnan Zaid \\ Universitas Teknologi Yogyakarta \\ adnan56zaid@yahoo.com
}

\begin{abstract}
Upon completing all the required courses, master's students in Indonesia are to write a thesis. Thesis writing, to some extent, haunts the students, especially when they have to conduct it in English. The problems are not only concerned with the contents of their thesis, but also with linguistic problems on how to write well with good basic command of English. The linguistic problems can cause their sentences to be not grammatically acceptable, or even sometimes not readable.

This paper will explore the linguistic problems faced by master's students in their thesis writing such as the ones related to diction, tenses, concord, articles, sentence patterns, to infinitive, gerund, and participle. It will also deal with how to solve the problems by giving the students some treatment while they are in the process of writing their thesis. The data will be taken from master's students' thesis drafts. The students are under the writer's supervision.
\end{abstract}

Keywords : thesis writing, linguistic problems, master's students

\section{Introduction}

Writing is different from speaking in the sense that what is written can last long and can be read again and again while the spoken form will disappear soon unless it is recorded. To some good writers, writing can be just like flowing water. The ideas come out continuously. However, to some common people, writing can be daunting and frustrating task ( Ferris, 2011: 1). When it is done in the target language where the

Dealing with Linguistic Problems Faced by Master's Students in their Thesis 22 Writing 
mastery of it has not been adequate yet, it can be more arduous. It is not like writing in an L1, writing in an $L 2$ requires an attainment of sufficient L2 linguistic proficiency (Hinkel, 2004:7). In fact, some acquirers of L2 may never attain native-like control of various aspects of the L2 (Ferris, 2011:9).

It has been debatable whether it is necessary for teachers to correct students' errors in writing. Some argue that making errors is just a step that has to be made in order to progress, while others assert that errors can be fossilized if they are not corrected. Fossilization may hinder the progress ahead. Some studies show that error feedback can help students to improve of their writing. Students value teacher feedback on their errors and think that it helps them to improve their writing (Ferris, 2011:13).

Teachers are responsible for correcting the students' errors in writing, especially when the students write scientific articles. However, teacher responses to students' writing tend to focus on error correction and identifying problems in students' control of language rather than how meanings are being conveyed (Hyland, 2009:10). It is understandable in the case that the students are still in the process of learning the target language.

In thesis and dissertation writing where English is not the students' native language, the writing problems can be more than just linguistic matters. The supervisors are also burdened with cultural, familial and professional pressures (Paltridge and Starfield, 2007:22). The span of time for writing, the students' background knowledge, the purpose of writing, and the kind of research must be taken into account by the supervisors. They need some strategies to help students finish their theses on time and at the same time the students learn things related to linguistic problems in writing.

\section{Kinds of Linguistic Errors}

In their theses dratfs, the students made errors in various aspects of English grammar rules. The errors ranged from a very trivial one up to the most complicated one. The errors happened, for instance, in the use of article, sentence patterns, tenses, diction, parallelism, concord, gerund, to infinitive, and participle. Just to give some illustration, here are some examples of errors made by the students in the drafts of their theses. 


\begin{tabular}{|c|c|c|}
\hline $\begin{array}{l}\text { Aspect of } \\
\text { grammar }\end{array}$ & Students' work & Type of errors \\
\hline article & $\begin{array}{l}\text { Writing is ... very eminent skill in } \\
\text { English }\end{array}$ & $\begin{array}{l}\text { omission of an } \\
\text { article a }\end{array}$ \\
\hline tenses & $\begin{array}{l}\text { It was hoped that the students } \\
\text { can be more active during } \\
\text { teaching learning process }\end{array}$ & $\begin{array}{l}\text { Wrong tenses; } \\
\text { present tense } \\
\text { instead of past } \\
\text { tense }\end{array}$ \\
\hline concord & ... a writer develop a subject & $\begin{array}{l}\text { omission of } s \text { at } \\
\text { the end of the } \\
\text { verb }\end{array}$ \\
\hline sentence pattern & $\begin{array}{l}\text { The students are hard to } \\
\text { understand the text }\end{array}$ & $\begin{array}{l}\text { wrong use of the } \\
\text { pattern of "find it } \\
+ \text { adjective to } \\
\text {..." }\end{array}$ \\
\hline to infinitive & $\begin{array}{l}\text { The researcher asked one of the } \\
\text { students to became the leader }\end{array}$ & $\begin{array}{l}\text { wrong use of to } \\
\text { infinitive }\end{array}$ \\
\hline gerund & $\begin{array}{l}\text { The students did the test without } \\
\text { to look at the instruction }\end{array}$ & $\begin{array}{l}\text { preposition } \\
\text { should } \\
\text { followed } \\
\text { gerund }\end{array}$ \\
\hline diction & ... the action could be continuous & $\begin{array}{l}\text { an adjective } \\
\text { instead of a verb }\end{array}$ \\
\hline parallelism & $\begin{array}{l}\text { They did not read the text } \\
\text { carefully and reluctant to discuss } \\
\text { the text }\end{array}$ & $\begin{array}{l}\text { the use of an } \\
\text { adjective instead } \\
\text { of a verb }\end{array}$ \\
\hline participle & $\begin{array}{l}\text { Giving the assignment, the } \\
\text { students felt frustrated. }\end{array}$ & $\begin{array}{lr}\text { past participle } \\
\text { instead of } \\
\text { present participle }\end{array}$ \\
\hline
\end{tabular}

When the students made some errors, the instructor tried to make them right by giving some feedback to the students.

\section{Procedure of Giving Feedback}

The students were assigned to hand in their thesis drafts twice a week. The instructor made some feedback on the collected drafts and returned them to the students who were given some time to learn about errors they made. The instructor wrote some notes, or put some red marks on the sentences or words which needed revising. After the students read some feedback from their instructor, a conference was held. It could be one-to-one conference or a group one. When there were some errors in common among the students, a group conference was held. After the conference, the students revised their drafts and handed them in again to the instructor. This cycle could happen many times until the students got their drafts right.

Dealing with Linguistic Problems Faced by Master's Students in their Thesis 24 Writing 
The instructor usually showed the students' errors and asked the students why they made the errors. Some of them realized their errors but many of them needed some explanation on why they made the errors. Most of the time, the discussion was on comparing some grammar rules in Indonesian and English. The instructor, at times, had to explain the basic English grammar rules when the students made serious errors.

\section{Students' Impression}

The students were asked to write their impression on their thesis writing, including some difficulties that they might encounter while writing their thesis. Here are some examples of the students' impression on the way they got some guidance while writing their theses:

One student wrote about linguistic problems she encountered as follows: (not edited)

I have difficulties in :

- choosing the appropriate words (diction) and vocabulary.

- Very often forget writing article (a, an/ the)

- Writing Noun Phrase (paraphrasing)

- Choosing conjunction

In relation to the difficulties in writing his thesis, another student stated as beneath: (not edited)

I have many problems there, they are : vocabulary, grammar, my limitation make beautiful sentences, etc. Alhamdulillah all of my problems can be clear because of my favorite lecture, he to be patient to help me in writing thesis. It's doesn't instant like other lectures can be four or five times only to guidance, may be start from chapter I up to five can be 30 times to guidance, but I am satisfied of them. Now there are many things that I know from him, many problems that I have and now all my problems are clear, from easy up to difficult problems he can help to be clear.

Still in relation to the difficulty in writing a thesis, one student explained her difficulty in writing her thesis :

It was not the easy one that I had to write my thesis at that time as one of my tasks to finish my study

About the way the instructor conducted consultancy and gave some feedback, here are some comments from the students: (not edited)

One student wrote that the consultancy was fruitful and useful for her thesis writing. 
He is a very generous kind humble helpful person who always helps students for example, he has willing to lend his books, reply our messages and giveconsultacy anytime the students have difficulties in managing time.

It was always wonderful and precious time when we meet bcause he always gives me sermon, suggestion, advice about life and about my carrier.

Another student commented on the instructor's way of giving consultancy: (not edited)

1. Motivating the student to write better and have broaden mind concerning the issues.

2. Showing the personal careness for the students so they feel like they have a friend to share the ideas.

3. Concerning the details of the writing...so the writing would only have minor mistakes or even zero one.

4. Giving abundant ideas if the students have deadlock for the writing, but still the students who decide where to go. ()

Another student confessed that she could learn something more than just grammar: (not edited)

He guided me finishing the thesis patiently, since I recognized myself I am not good at grammar at all. He was smartly showing me how to put words into a meaningful construction. He did more than being a supervisor, nevertheless a father, a motivator for me. I learnt how to manage this life well, how to be useful for others and many things.

Another student claimed that the consultancy was effective: (not edited)

Consulting twice a week on Wednesday and Saturday were effective. We had enough time to prepare our draft before submitted it on the next day. You know....we would be waiting for your SMS on Tuesday night and Friday night and hoped that you did not send SMS about canceling consulting.

A student admitted that she was confused at the beginning, but then she could overcome her problem: (not edited)

You are very friendly and had pretension to help me to complete my thesis. You explained patiently when I was confuse to comprehend the ideas of my writing. You are really open minded when you guided the students so we could understand our weaknesses and things that we should be corrected in our writing.

Dealing with Linguistic Problems Faced by Master's Students in their Thesis 26 Writing 
You never underestimated what we had written even though you should corrected word by word.

Another student felt that she could be motivated to write her thesis: (not edited)

Absolutely, I loved the way guided me in writing. Step by step, everything was running well. You really showed me the way to write clearly. From the first chapter to the last, i felt that i could do it without any serious difficulties. Everything seemed to be easy. And the important thing is that you could help me to strengten me when i was so weak to finish the two last parts.

What I want to tell you then is that your way of guiding has not only improved my English and writing skill but also inspired and taught me many aspects of life. You know, I have learnt that in this life I have to be serious, disciplined, avoid faults, nice or beautiful, motivated, and other good things that I have to apply in my family, working place, village, and wherever.

A student realized that he could learn from his errors after he consulted with the instructor: (not edited)

Your way of correcting is very good Sir. You crossed the mistakes, but you also showed the corrections. If the mistakes happened many times, you wrote signs or simple words to tell that the mistakes were the same as the ones before. When the idea or content was totally wrong, you just wrote 'See me!'. I think such a way of correction is excellent.

Another student firstly complained about the feedback, but then he realized the benefit of it. (not edited)

Sometimes I grumbled when you corrected my mistake on dictions because I thought my words were okay, but it seemed that you wanted more; you wanted me to use beautiful and more appropriate words in my sentences. I was learning here. I had to produce words which are not only understandable but also comfortable to read. Of course, I got new words from here.

Another student thought that his English grammar was good enough, but then he admitted that he still made errors. (not edited)

I felt that I was good enough at grammar since it is my favorite subject, but in fact you still showed me my mistakes although they were not the serious ones. As a consequence, I could be more and more careful in writing. I struggled hard in order that I made no Dealing with Linguistic Problems Faced by Master's Students in their Thesis 27 Writing 
mistakes. I often read my draft repeatedly in case there were still some mistakes before submitting it to you because I knew that you would soon find them if I still made any, even the very small ones. Alhamdulillah, from day to day, my grammatical mistakes kept decreasing.

A student felt that he learned something after he consulted with the instructor to talk about his thesis draft: (not edited)

It's so different with other supervisor. In fact, I got many lessons from him. By writing chapter by chapter, he could see and check my thesis and found my mistakes till the little one, so accurate that I realized that it was my wrong. He directed my writing patiently and pleasantly.

Two students claimed that they could apply the way the instructor gave consultancy to their own setting: (not edited)

One of my tasks in my office is that I have to edit art and crats modules for teachers, because of him I do the job is more thorough and serious, and I always tell him to say thankyou about his guidance.

It was a good challenge for me when you guided my thesis writing. You scheduled the thesis supervising and only checked a few parts of it and gave example of good writing. You asked me to be creative to make a better writing based on what you told me and I did it. Because of it, I accomplished my thesis writing in five months. Now, I adopt the way of your supervising to my students.

The students responded positively to the way the instructor held consultancy and gave some feedback while the process of the thesis writing was going on. Oftentimes, the instructor had to adjust to the students' pace in writing and understanding about the grammar rules. As a rule of thumb, the slow writers took longer time to comprehend the instructor's explanation so that they had to see the instructor again and again.

\section{Conclusion}

It can be inferred that the students still made some grammatical errors in their thesis writing although they had been in the master's program. They badly needed some correction or feedback from the instructor to make some betterment in their writing.

The linguistic errors that the students made are varied. They can be in article, sentence patterns, tenses, diction, concord, gerund, to infinitive, and participle.

The students admitted that consulting with their instructor gave them positive impact. They could learn from their errors, and could make Dealing with Linguistic Problems Faced by Master's Students in their Thesis 28 Writing 
their writing better. They also realized that their English was not as good as they thought before. Some of them were motivated to work harder, and some wanted to apply the technique used by the instructor in their own setting later on when they returned to their home towns.

Although the students had been learning English for quite long time, their mastery of English grammar rules was not adequate yet so that they needed some help from the instructor to refine their thesis, both in linguistic aspects and the contents as well.

It needed much time and patience, from the instructor's part, to give consultancy to the students when they were writing their thesis. The instructor had to build a good rapport with the students so that they students could eat his words. Personal approach and much understanding played an important role in this matter.

\section{References}

Corbert, J. 2003. An Intercultural Approach to English Language Teaching.Clevedon: Multilingual Matters Ltd.

Ferris, D.R. 2011. Treatment of Error in Second Language Student Writing. Ann Arbor: The University of Michigan Press.

Hinkel, E. 2004. Teaching Academic ESL Writing: Practical Techniques in Vocabulary and Grammar. London: Lawrence Erlbaum Associates

Hyland, K. 2009. Teaching and Researching Writing. Harlow: Pearson Education Limited.

Paltridge, B. \& Sue Starfield. 2007. Thesis and Dissertation Writing in Second Language: A Handbook for Supervisors. Oxon: Routledge

Wallwork, A. 2010.English for Presentations at International Conferences. New York: Springer.

Springer 2011. English for Writing Research Papers. New York: 